\author{
대구지역 학교급식 나트륨 저감화 실태 및 \\ 나트륨 저감화 방법에 대한 중요도-수행도 분석 \\ 김수현 ${ }^{1)}$ • 신은경 ${ }^{2)}$ • 이연경 ${ }^{3) \dagger}$ \\ 1)경북대학교 교육대학원 영양교육전공, 대학원생, ${ }^{2) ㄱ ㅕ ㅇ ㅂ ㅜ ㄱ ㄷ ㅐ ㅎ ㅏ ㄱ ㄱ ㅛ ~ ㅅ ㅣ ㄱ ㅍ ㅜ ㅁ ㅇ ㅕ ㅇ ㅇ ㅑ ㅇ ㅎ ㅏ ㄱ ㄱ ㅘ, ~ ㅅ ㅣ ㄱ ㅏ ㄴ ㄱ ㅏ ㅇ ㅅ ㅏ ~}$ \\ 3)경북대학교 식품영양학과 및 장수생활과학연구소, 교수
}

\title{
Sodium Reduction Practice and Importance-Performance Analysis of Sodium Reduction Methods in School Foodservice in Daegu
}

\author{
Su-Hyeon Kim ${ }^{1)}$, Eun-Kyung Shin ${ }^{2)}$, Yeon-Kyung Lee ${ }^{3) \dagger}$ \\ ${ }^{1)}$ Graduate student, Nutrition Education Major, Graduate School of Education, Kyungpook National University, Daegu, Korea \\ ${ }^{2}$ Instructor, Food Science and Nutrition, Kyungpook National University, Daegu, Korea \\ ${ }^{3)}$ Professor, Food Science and Nutrition and Center for Beautiful Aging, Kyungpook National University, Daegu, Korea
}

\section{Corresponding author \\ Yeon-Kyung Lee \\ Department of Food Science and Nutrition, Kyungpook National University, 80, Daehak-ro, Buk- gu, Daegu 41566, Korea}

Tel: (053) 950-6234

Fax: (053) 950-6229

E-mail: yklee@knu.ac.kr

Received: September 1, 2020 Revised: October 27, 2020 Accepted: October 28, 2020

\begin{abstract}
Objectives: The aim of this study was to investigate sodium reduction practices in school foodservice in Daegu.

Methods: The survey included 199 nutrition teachers and dietitians working at elementary, middle and high schools in Daegu. The survey topics included the following: the frequency of salinity measurement, workers in charge of the measurement, average salinity of the soup and stew served, frequency and difficulties of offering low-sodium meals, Importance-Performance Analysis (IPA) of sodium reduction methods in school foodservice and the need for political support in encouraging sodium reduction.
\end{abstract}

Results: The mean salinity of the soup and stew was higher in high school foodservice than in elementary and middle school foodservice. Middle and high schools have difficulties in offering low-sodium meals due to concerns of decreasing satisfaction for the meals. The results of the IPA of programs to reduce sodium in school meals showed that most of the items in the cooking and serving stages were in the 2nd quadrant (Keep up the good work), and all purchasing and menu planning stages occupied the 3rd quadrant (Low priority). To reduce sodium in school meals, government support is required in developing low-sodium recipes for school foodservice, encouraging education on sodium reduction for school foodservice officials and developing low-sodium food for institutional foodservice.

Conclusions: To encourage sodium reduction in school meals, the priority is to make low-sodium recipes available. Also, it is necessary to develop a program that calculates the sodium content in menus and processed foods through National Education Information System and to establish standards for sodium levels in school foodservice.

Korean J Community Nutr 25(5): 386 395, 2020

KEY WORDS sodium reduction, school foodservice, Importance-Performance Analysis

This is an Open-Access article distributed under the terms of the Creative Commons Attribution Non-Commercial License (http:// creativecommons.org/licenses/by-nc/3.0) which permits unrestricted non-commercial use, distribution, and reproduction in any medium, provided the original work is properly cited. 


\section{서 론}

2019년 2월 말 학교급식 통계 기준 전국 초 · 중 · 고 · 특 수학교 전체 11,818 개교에서 561만명에게 급식을 제공하 고 있다 [1]. 성장기의 대부분을 차지하는 청소년기에 1 2 끼를 학교급식에 의존하고 있는 상황으로 학교급식의 나트 륨 저감화가 학생들의 건강과 성장에 매우 중요한 영향을 미 치게 된다. 이에 교육부 [2]는 학교급식의 나트륨 저감화를 위하여 급식 1 끼당 나트륨 함량을 초등학교 $900 \mathrm{mg}$, 중학 교 $1,000 \mathrm{mg}$, 고등학교 $1,300 \mathrm{mg}$ 제공하도록 권장하였 다. 또한 학교급식 국 - 찌개의 염도 기준을 초등학교와 중학 교는 $0.6 \%$ 이하, 고등학교는 $0.7 \%$ 이하로 저염화하고 국 배식량을 초등학교 $100 \mathrm{ml}$, 중학교 $130 \mathrm{ml}$, 고등학교 150 $\mathrm{ml}$ 이하로 줄일 것을 권장하였다.

2012년 조사된 경기지역 전체 초 · 중 · 고 학교급식에서 국이나 찌개의 염도를 측정하는 비율은 $62.7 \%$ 였고, 염도를 공지하는 비율은 $15.4 \%$ 에 불과하였으며, 국이나 찌개의 염 도는 0.7 0.8\%가 49.0\%로 가장 많았고 [3], 영양(교)사 의 $90.5 \%$ 가 저염제품을 사용하지 않았다 [4]. 2014년 서울 지역 학교급식에서는 국 염도 측정 비율이 $70.8 \%$, 식단작성 시 나트륨 저감화를 위해 노력하는 비율이 $77.5 \%$ 로 나타났 다 [5]. 2015년 부산지역 학교급식에서는 양념에 재운 고기 보다 생고기를 사용하고, 국 - 찌개 간을 마지막에 맞추는 등 의 나트륨 저감화 방법을 실천하고 있었다 [6]. 2015년 울 산지역 학교급식에서는 국의 염도 측정 비율이 $97.3 \%$ 였고, 맑은 국은 $0.59 \%$, 전체 국 염도는 $0.7 \%$ 를 넘지 않는 것으 로 조사되었다[7]. 2015년 제주지역에서는 모든 학교가 $100 \%$ 염도계를 사용하고, $86.4 \%$ 가 식단 계획 시 나트륨 저감화를 위해 노력하고 있었다 [8].

이처럼 학교급식 나트륨 저감화에 대한 인식도 및 저감화 실태에 관한 조사연구가 지역별로 보고되고 있으나 [3-8], 대구지역에서는 실태조사가 전혀 이루어지지 않았다. 또한 나트륨 저감화 방법에 대한 중요도와 수행도를 분석하여 나 트륨 저감화 방법이 중요도는 높으나 잘 수행되고 있지 않은 것 (Concentrate here), 증요하면서 잘 수행되고 있는 것 (Keep up the good work), 중요도와 수행도가 모두 낮은 것 (Low priority) 과 중요도는 낮지만 잘 수행하고 있는 것 (Possible overkill)을 파악함으로써 향후 나트륨 저감화를 효과적으로 활성화하는 방안을 도출할 필요가 있다.

따라서 본 연구에서는 대구지역 초 - 중 · 고등학교 영양 (교)사들을 대상으로 학교급식 나트륨 저감화 실태 및 나트 륨 저감화에 대한 정책적 지원의 필요성을 조사하고, 나트륨
저감화 방법에 대한 중요도와 수행도를 분석하여, 학교급식 나트륨 저감화를 위한 기초자료로 제공하고자 한다.

\section{연구대상 및 방법}

\section{1. 연구 대상 및 시기}

본 연구는 대구광역시교육청에 협조를 요청하여 2018년 2 월 5 일부터 4 월 15 일까지 약 2 개월간에 걸쳐 대구시 소재 초등학교 (229개교), 중학교 (125개교) 및 고등학교 (93개 교)에 근무하는 영양(교)사 전체 450명을 대상으로 설문조 사를 실시하였다. 설문조사는 온라인과 우편으로 실시하였 으며, 회수된 설문지는 초등학교 129 부, 중학교 46부, 고등 학교 24 부로 총 199 부였으며, 회수율은 $44.2 \%$ 였다. 본 연 구는 경북대학교 생명윤리위원회 (IRB)의 승인 하에 실시되 었다(KNU 2017-140).

\section{2. 연구 내용 및 방법}

본 조사에 사용된 설문지는 선행연구 [3-8] 설문지를 수 정 · 보완 후 사용하였다.

나트륨 저감화 실태 조사 항목으로는 급식의 염도 측정 여 부 및 빈도, 염도 측정담당자, 국 · 찌개류의 평균 염도, 저나 트륨 식단 제공 빈도와 가공식품의 사용빈도, 나트륨 저감화 의 어려운 점을 포함하였다. 급식종사자 (조리사, 조리종사 원) 대상 나트륨 저감화 관련 교육 실시 여부와 교육 방법을 조사하였으며, 나트륨 저감화 활성화를 위한 정책적 지원의 필요성에 대한 조사 문항에 대하여 Likert 5 점 척도로 조사 하였다.

학교급식 나트륨 저감화 방법에 대한 중요도와 수행도는 구매단계 2항목, 식단작성단계 4항목, 조리단계 6항목, 배식 단계 3 항목의 총 15 항목에 대하여 Likert 5 점 척도로 조사 하였다. 구매단계는 ‘구매 시 나트륨 함량 확인하기’, ‘저염 양념류 구매하기', 식단작성 단계는 '나트륨 함량 고려하여 식단 작성하기', ‘칼륨 풍부한 식단 작성하기', ‘한두 음식에 만 집중적으로 간하도록 식단 조정하기', ‘가공완제품 사용 하는 대신 직접 조리하도록 식단 작성하기', 조리단계에서는 ‘채소 (김치) 절일 때 소금 대신 소금물 이용하기', ‘천연조미 료 (다시마, 멸치, 버섯 등) 사용하기', '쌈장이나 된장은 두 부와 양파를 넣어 염도 낮추기', ‘소금과 장류 사용량 줄이고 대신 향신료, 허브, 들깨가루 등 사용하기', ‘국이나 찌개는 끓인 후 마지막에 간하기', '어육가공품은 데친 후 조리하기', 배식단계는 ‘양념장 별도 배식하기', ‘용량 작은 국그릇 사용 하거나 양을 적게 배식하기', ‘국 · 탕 - 찌개류 염도 게시하 기’의 문항으로 구성되었다. 
388 - 학교급식 나트륨 저감화실태 및 중요도-수행도 분석

\section{3. 통계처리}

본 연구 결과는 IBM SPSS Statistics 25 (IBM Corporation, Armonk, NY, USA) 프로그램을 사용하여 분석하였다. 초 · 중 · 고등학교 학교 급별 나트륨 저감화 실 태와 교육실태는 빈도분석을 실시하였고, 국류와 찌개류의 평균 염도와 나트륨 저감화 방법에 대한 중요도와 수행도 간 차이는 대응표본 $\mathrm{t}$-test로 분석하였다. 중요도-수행도 분 석 (Importance-Performance Analysis, IPA)을 위하 여 수행도를 $\mathrm{X}$ 축으로, 중요도를 $\mathrm{Y}$ 축으로 표시하고 중요도와 수행도의 평균값을 각 축의 기준으로 하여 사분면의 격자도 를 구성하고 좌표점을 표시하였다. 또한 나트륨 저감화를 위 한 정책적 지원의 필요성에 대한 학교 급별 비교는 ANOVA 와 Duncan's multiple comparison test를 통해 차이를 분석하였다.

\section{결 과}

\section{1. 학교급식 나트륨 저감화 실태}

학교급식 나트륨 저감화 실태는 Table 1과 같다. 급식 음 식 염도는 초 · 중 - 고등학교 모두 $100 \%$ 측정하고 있으며, $98.5 \%$ 가 매일 측정하였다. 염도 측정담당자는 전체적으로 조리사가 $59.3 \%$ 로 가장 많았고, 그다음 영양 (교)사 (39.3\%) 였으며, 초등학교와 중학교에서는 조리사가 측정하는 비율 이 높았고, 고등학교에서는 영양사가 측정하는 비율이 높아 학교 급별 유의한 차이가 있었다 $(P<0.001)$. 저나트륨 식 단은 초등학교의 $33.3 \%$ 가 매일 제공하였고, 중학교는 월 $1 \sim 2$ 회 제공하는 경우가 $34.8 \%$ 로 가장 높았으며, 고등학교 는 월 1 2회, 주 1 2회 제공하는 경우가 각각 $29.2 \%$ 로 높 았다. 즉 저나트륨 식단을 주 1 회 이상 제공하는 비율이 초

Table 1. Current status of sodium reduction in school foodservice in Daegu

\begin{tabular}{|c|c|c|c|c|c|}
\hline Item & Elementary school & Middle school & High school & Total & $\chi^{2}$ \\
\hline \multicolumn{6}{|l|}{ Salinity measurement } \\
\hline Yes & $129(100.0)$ & $46(100.0)$ & $24(100.0)$ & $199(100.0)$ & \\
\hline No & $0(0.0)$ & $0(0.0)$ & $0(0.0)$ & $0(0.0)$ & \\
\hline \multicolumn{6}{|l|}{ Frequency of salinity measurement } \\
\hline Every day & $126(97.7)$ & $46(100.0)$ & $24(100.0)$ & $196(98.5)$ & 1.653 \\
\hline $3 \sim 4$ times/week & $2(1.5)$ & $0(0.0)$ & $0(0.0)$ & $2(1.0)$ & \\
\hline 1 2 times/week & $0(0.0)$ & $0(0.0)$ & $0(0.0)$ & $0(0.0)$ & \\
\hline 1 2 times/month & $1(0.8)$ & $0(0.0)$ & $0(0.0)$ & $1(\quad 0.5)$ & \\
\hline Others & $0(0.0)$ & $0(0.0)$ & $0(0.0)$ & $0(0.0)$ & \\
\hline \multicolumn{6}{|c|}{ Person in charge of salinity measurement } \\
\hline Dietitian (nutrition teacher) & $40(31.0)$ & $22(47.8)$ & $17(70.8)$ & $79(40.0)$ & $24.910 * * *$ \\
\hline Cook & $89(69.0)$ & $24(52.2)$ & $6(25.0)$ & $119(60.1)$ & \\
\hline Cooking staff & $0(0.0)$ & $0(0.0)$ & $1(4.2)$ & $1(\quad 0.5)$ & \\
\hline \multicolumn{6}{|c|}{ Frequency of serving low sodium meals } \\
\hline Every day & $43(33.3)$ & $5(10.9)$ & $2(8.3)$ & $50(25.1)$ & $22.975^{*}$ \\
\hline $3 \sim 4$ times/week & $17(13.2)$ & $2(4.3)$ & $2(8.3)$ & $21(10.6)$ & \\
\hline $1 \sim 2$ times/week & $21(16.3)$ & $12(26.1)$ & $7(29.2)$ & $40(20.1)$ & \\
\hline $1 \sim 2$ times/month & $20(15.5)$ & $16(34.8)$ & $7(29.2)$ & $43(21.6)$ & \\
\hline No serving of low sodium meals & $17(13.2)$ & $5(10.9)$ & $4(16.7)$ & $26(13.1)$ & \\
\hline Others & $11(8.5)$ & $6(13.0)$ & $2(8.3)$ & $19(9.5)$ & \\
\hline \multicolumn{6}{|l|}{ Frequency of using processed foods } \\
\hline Every day & $0(0.0)$ & $0(0.0)$ & $0(0.0)$ & $0(0.0)$ & $52.538 * * *$ \\
\hline $3 \sim 4$ times/week & $1(0.8)$ & $6(13.0)$ & $6(25.0)$ & $13(6.5)$ & \\
\hline $1 \sim 2$ times/week & $53(41.1)$ & $28(60.9)$ & $18(75.0)$ & $99(49.7)$ & \\
\hline $1 \sim 2$ times/month & $75(58.1)$ & 11 ( 23.9) & $0(\quad 0.0)$ & $86(43.3)$ & \\
\hline Others & $0(0.0)$ & $1(2.2)$ & $0(\quad 0.0)$ & $1(\quad 0.5)$ & \\
\hline Total & 129 (100.0) & 46 (100.0) & 24 (100.0) & 199 (100.0) & \\
\hline
\end{tabular}

$\mathrm{n}(\%), * P<0.05, * * * P<0.001$ 
등학교는 $62.8 \%$, 중학교는 $41.3 \%$, 고등학교는 $45.8 \%$ 로 초등학교에서 중고등학교보다 저나트륨 식단 제공 빈도가 유 의하게 높은 것으로 나타났다 $(P<0.05)$. 가공식품의 사용 빈도는 전체적으로 주 1 2회 제공하는 경우가 가장 많았으 며, 초등학교의 경우 월 1 2회 제공하는 경우가 $58.1 \%$, 주 1 2회 제공하는 경우 $41.1 \%$ 였으나, 중학교는 주 1 2회가 $60.9 \%$, 주 $3 \sim 4$ 회가 $13 \%$, 고등학교는 주 1 2회가 $75.0 \%$, 주 3 4회가 $25 \%$ 로 나타나서 초등학교에 비하여 중고등학교에서 가공식품 제공 빈도가 유의하게 높았다 $(P$ $<0.001)$.

학교급식 국류 및 찌개류의 평균 염도는 Table 2 와 같다. 학교 급별 국류의 평균 염도는 초등학교가 $0.50 \%$ 이고, 중학 교는 $0.52 \%$, 고등학교는 $0.54 \%$ 로 나타났으며, 고등학교가 초등학교에 비해 국류의 평균 염도가 유의하게 더 높았다 $(P$ < 0.05). 학교 급별 찌개류의 평균 염도는 초등학교가 $0.58 \%$, 중학교는 $0.62 \%$, 고등학교는 $0.66 \%$ 로 나타나 고 등학교에서 가장 높았으며 초등학교에서 가장 낮았다 $(P<$ $0.001)$. 또한 찌개류의 염도 $(0.60 \%)$ 가 국류의 염도 $(0.51 \%)$ 보다 전체적으로 유의하게 높았다 $(P<0.001)$.
학교급식에서 저나트륨 식단 제공이 어려운 이유는 Table 3 과 같다. '급식 만족도 저하에 대한 우려'가 전체 $27.3 \%$ 로 가장 높았고, '학생 · 교직원 등 피급식자 인식과 실천의식 부족’이라고 답한 경우도 $21.8 \%$ 로 높게 나타났다.

\section{2. 학교급식 나트륨 저감화 방법에 대한 중요도와 수행도}

학교급식의 나트륨 저감화 방법에 대한 중요도와 수행도 분석 결과는 Table 4 와 같다. 나트륨 저감화 방법 중에서 ‘천연조미료 사용하기'는 중요도와 수행도가 각각 4.87점, 4.89점으로 가장 높았으며, 중요도와 수행도간에 유의한 차 이는 없었다. 다음은 ‘국 · 탕 - 찌개류의 염도 게시하기'의 중요도와 수행도가 높았으며, 이 항목은 중요도 (4.69)에 비 하여 수행도 (4.84)가 유의하게 높은 항목이었다 $(P<0.05)$. 그 다음은 '어육가공품은 데친 후 조리하기', ‘국 - 찌개는 끓 인 후 마지막에 간하기, 순으로 나타났으며, 이들 항목의 중 요도와 수행도 간에 유의한 차이는 없었다.

전체적으로 볼 때 나트륨 저감화 방법의 수행도 (4.12)가 중요도 (4.32)에 비하여 유의하게 낮은 것으로 나타났다 $(P$ < 0.001). 중요도 보다 수행도가 유의하게 낮았던 항목으로

Table 2. Comparison of average salt levels between soup and stew served in school foodservice

\begin{tabular}{|c|c|c|c|c|c|}
\hline Item & Elementary school & Middle school & High school & Total & F-value \\
\hline Soup & $\begin{array}{c}0.50 \pm 0.06^{a} \\
(n=129)\end{array}$ & $\begin{array}{c}0.52 \pm 0.07^{\mathrm{ab}} \\
(\mathrm{n}=46)\end{array}$ & $\begin{array}{c}0.54 \pm 0.09^{b} \\
(n=24)\end{array}$ & $\begin{array}{c}0.51 \pm 0.07 \\
(n=199)\end{array}$ & $4.221 *$ \\
\hline Stew & $\begin{array}{c}0.58 \pm 0.08^{a} \\
(n=117)\end{array}$ & $\begin{array}{c}0.62 \pm 0.07^{b} \\
(n=42)\end{array}$ & $\begin{array}{c}0.66 \pm 0.07^{c} \\
(n=24)\end{array}$ & $\begin{array}{c}0.60 \pm 0.08 \\
(n=183)\end{array}$ & $16.852 * * *$ \\
\hline T-value & $-8.549 * * *$ & $-6.914 * * *$ & $-5.464 * * *$ & $-11.723 * * *$ & \\
\hline
\end{tabular}

Mean \pm S.D., $* P<0.05, * * * P<0.001$

Means with different lower case letters in the same row are significantly different by Duncan's multiple range test at $P<0.05$.

Table 3. Difficulties in providing low-sodium menu in school foodservice ${ }^{11}$

\begin{tabular}{|c|c|c|c|c|}
\hline Item & Elementary school & Middle school & High school & Total \\
\hline $\begin{array}{l}\text { Lack of school meal users (students, teachers, etc.)' } \\
\text { awareness and practice }\end{array}$ & $81(20.9)$ & $30(21.7)$ & $19(26.4)$ & $130(21.8)$ \\
\hline $\begin{array}{l}\text { Lack of school meal staff (cooks, cooking staff, etc.)'s } \\
\text { awareness and practice }\end{array}$ & $18(4.7)$ & $10(7.2)$ & $4(5.5)$ & $32(5.4)$ \\
\hline Lack of school parents' awareness and practice & $32(8.3)$ & $8(5.8)$ & $2(2.8)$ & $42(7.0)$ \\
\hline $\begin{array}{l}\text { Concern about a possible decrease in school meal } \\
\text { satisfaction }\end{array}$ & $103(26.6)$ & $40(29.0)$ & $20(27.8)$ & $163(27.3)$ \\
\hline Difficulties in developing low-sodium diets & $68(17.6)$ & $19(13.8)$ & $10(13.9)$ & $97(16.2)$ \\
\hline Lack of educational materials about sodium reduction & $19(4.9)$ & $4(2.9)$ & $5(6.9)$ & $28(4.7)$ \\
\hline Lack of sodium reduction manuals & $54(13.9)$ & $20(14.5)$ & $10(13.9)$ & $84(14.1)$ \\
\hline $\begin{array}{l}\text { Lack of guidelines and regulations about sodium reduction } \\
\text { provided by the Ministry of Education }\end{array}$ & $12(3.1)$ & $7(5.1)$ & $2(2.8)$ & $21(3.5)$ \\
\hline Total & 387 (100.0) & 138 (100.0) & 72 (100.0) & $597(100.0)$ \\
\hline
\end{tabular}

$\mathrm{n}(\%)$

1) Duplicate answers 
Table 4. Importance - Performance Analysis of sodium reduction methods in school foodservice

\begin{tabular}{|c|c|c|c|c|c|c|c|c|c|}
\hline \multirow[t]{2}{*}{ Item } & \multicolumn{3}{|c|}{$\begin{array}{l}\text { Elementary school } \\
\qquad(n=129)\end{array}$} & \multicolumn{3}{|c|}{$\begin{array}{l}\text { Middle or high School } \\
(n=70)\end{array}$} & \multicolumn{3}{|c|}{$\begin{array}{c}\text { Total } \\
(n=199)\end{array}$} \\
\hline & Importance & Performance & T-value & Importance & Performance & T-value & Importance & Performance & T-value \\
\hline Checking sodium content & $4.31 \pm 0.85$ & $3.96 \pm 1.06$ & $2.914^{* *}$ & $4.34 \pm 0.74$ & $3.93 \pm 1.09$ & $2.577^{*}$ & $4.32 \pm 0.81$ & $3.94 \pm 1.07$ & $3.910^{* * *}$ \\
\hline Choosing a low-sodium seasonings & $3.92 \pm 0.89$ & $3.35 \pm 1.11$ & $4.424 * * *$ & $4.04 \pm 0.90$ & $3.13 \pm 1.19$ & $5.074 * * *$ & $3.96 \pm 0.90$ & $3.27 \pm 1.14$ & $6.617^{* * *}$ \\
\hline Planning a low-sodium menu & $4.25 \pm 0.79$ & $4.01 \pm 0.91$ & $2.249 *$ & $4.15 \pm 0.88$ & $3.80 \pm 0.91$ & $2.269 *$ & $4.22 \pm 0.83$ & $3.93 \pm 0.92$ & $3.140 * * *$ \\
\hline Planning a high-potassium menu & $4.13 \pm 0.87$ & $3.75 \pm 0.99$ & $3.001 * *$ & $4.06 \pm 0.86$ & $3.41 \pm 0.99$ & $4.051 * * *$ & $4.10 \pm 0.87$ & $3.65 \pm 0.99$ & $4.798 * * *$ \\
\hline Planning a menu with only one or two salty dishes & $3.35 \pm 1.10$ & $3.14 \pm 1.11$ & 1.470 & $3.66 \pm 1.14$ & $3.33 \pm 1.22$ & 1.653 & $3.46 \pm 1.13$ & $3.21 \pm 1.16$ & $2.202^{*}$ \\
\hline Decreasing the use of processed foods & $4.37 \pm 0.81$ & $4.31 \pm 0.80$ & 0.608 & $4.19 \pm 0.79$ & $3.79 \pm 0.99$ & $2.644 * *$ & $4.31 \pm 0.81$ & $4.13 \pm 0.91$ & $2.054^{*}$ \\
\hline Soaking cabbage in brine instead of salting & $4.02 \pm 0.96$ & $3.98 \pm 1.18$ & 0.293 & $3.96 \pm 0.96$ & $3.59 \pm 1.10$ & $2.085^{*}$ & $3.99 \pm 0.97$ & $3.84 \pm 1.17$ & 1.425 \\
\hline Using natural seasonings & $4.89 \pm 0.36$ & $4.94 \pm 0.34$ & -1.059 & $4.84 \pm 0.61$ & $4.81 \pm 0.66$ & 0.220 & $4.87 \pm 0.47$ & $4.89 \pm 0.49$ & -0.482 \\
\hline Lowering salinity of seasonings & $4.53 \pm 0.67$ & $4.43 \pm 0.85$ & 1.022 & $4.38 \pm 0.88$ & $4.16 \pm 1.11$ & 1.321 & $4.48 \pm 0.76$ & $4.34 \pm 0.96$ & 1.614 \\
\hline Using more spice, herb or perilla powders & $4.27 \pm 0.80$ & $4.14 \pm 0.89$ & 1.217 & $4.32 \pm 0.85$ & $4.16 \pm 0.86$ & 1.139 & $4.29 \pm 0.82$ & $4.15 \pm 0.88$ & 1.667 \\
\hline Adding seasoning just before serving soup & $4.63 \pm 0.59$ & $4.60 \pm 0.61$ & 0.029 & $4.50 \pm 0.80$ & $4.54 \pm 0.73$ & -0.327 & $4.58 \pm 0.68$ & $4.58 \pm 0.66$ & -0.033 \\
\hline Blanching processed meat & $4.75 \pm 0.49$ & $4.78 \pm 0.51$ & -0.456 & $4.57 \pm 0.79$ & $4.56 \pm 0.77$ & 0.123 & $4.68 \pm 0.63$ & $4.70 \pm 0.63$ & -0.246 \\
\hline Serving seasonings separately & $4.49 \pm 0.78$ & $4.27 \pm 0.89$ & $2.057^{*}$ & $4.54 \pm 0.81$ & $4.43 \pm 0.82$ & $0.825^{*}$ & $4.51 \pm 0.79$ & $4.33 \pm 0.87$ & $2.165^{*}$ \\
\hline Using small soup bowl & $4.31 \pm 0.88$ & $4.19 \pm 0.88$ & 1.063 & $4.29 \pm 0.88$ & $3.70 \pm 1.17$ & $3.358 * * *$ & $4.31 \pm 0.88$ & $4.02 \pm 1.02$ & 2.939 \\
\hline Posting soup salinity & $4.69 \pm 0.63$ & $4.84 \pm 0.52$ & -1.908 & $4.69 \pm 0.73$ & $4.86 \pm 0.57$ & -1.479 & $4.69 \pm 0.67$ & $4.84 \pm 0.54$ & $-2.411^{*}$ \\
\hline Average & $4.33 \pm 0.46$ & $4.18 \pm 0.49$ & $2.409 *$ & $4.30 \pm 0.56$ & $4.01 \pm 0.52$ & $3.149 * * *$ & $4.32 \pm 0.50$ & $4.12 \pm 0.51$ & $3.83^{* * *}$ \\
\hline
\end{tabular}

Mean \pm S.D., $* P<0.05, * * P<0.01, * * * P<0.001$ 
는 ‘저염 양념류 구매하기' $(P<0.001)$, '영양표시의 나트 륨함량 확인하기' $(P<0.001)$, '칼륨이 풍부한 식단 작성하 기' $(P<0.001)$, '나트륨함량 고려하여 식단 작성하기' $(P<$ $0.001)$, '한 두 음식에만 집중적으로 간하도록 식단 조정하 기' $(P<0.05)$, '양념장은 별도 배식하기' $(P<0.05)$, '가 공완제품 대신 직접 조리하도록 식단 작성하기' $(P<0.05)$ 항목이었다.

전체 결과와는 다르게 초등학교와 중 - 고등학교를 분리하 여 분석한 결과에서는 두 집단 모두 ‘한두 음식에만 집중적 으로 간하도록 식단 조정하기', ‘국 · 탕 · 찌개류의 염도 게 시하기, 항목의 중요도와 수행도 간 유의한 차이가 없었다. 또한 초등학교와 달리 중고등학교에서는 '가공완제품 대신 직접 조리하도록 식단 조정하기' $(P<0.01)$, ‘채소 절일 때
소금 대신 소금물을 이용하기' $(P<0.05)$, '용량 작은 국그 릇 사용하거나 양을 적게 배식하기' $(P<0.001)$ 의 경우 중 요도에 비하여 수행도가 유의하게 낮은 것으로 나타났다.

학교급식의 나트륨 저감화 방법에 대한 중요도와 수행도 분석 (IPA)을 실시한 결과는 Fig. 1과 같다. 나트륨 저감화 방법 중 중요도는 높으나 수행도가 낮아 집중적으로 관리해 야하는 항목 (Concentrate here)은 없는 것으로 나타났다. 중요도가 높고 수행도도 높게 평가된 2사분면 (Keep up the good work)에는 8 (천연조미료 사용하기), 9 (쌈장, 된장은 두부나 양파 등을 갈아 염도를 낮추기), 11 (국 - 찌개는 끓 인 후 마지막에 간하기), 12 (어육가공품은 데친 후 조리하 기), 13 (양념장은 별도로 배식하기), 15 (국 · 탕 · 찌개류의 염도 게시하기) 항목이 해당되었다.

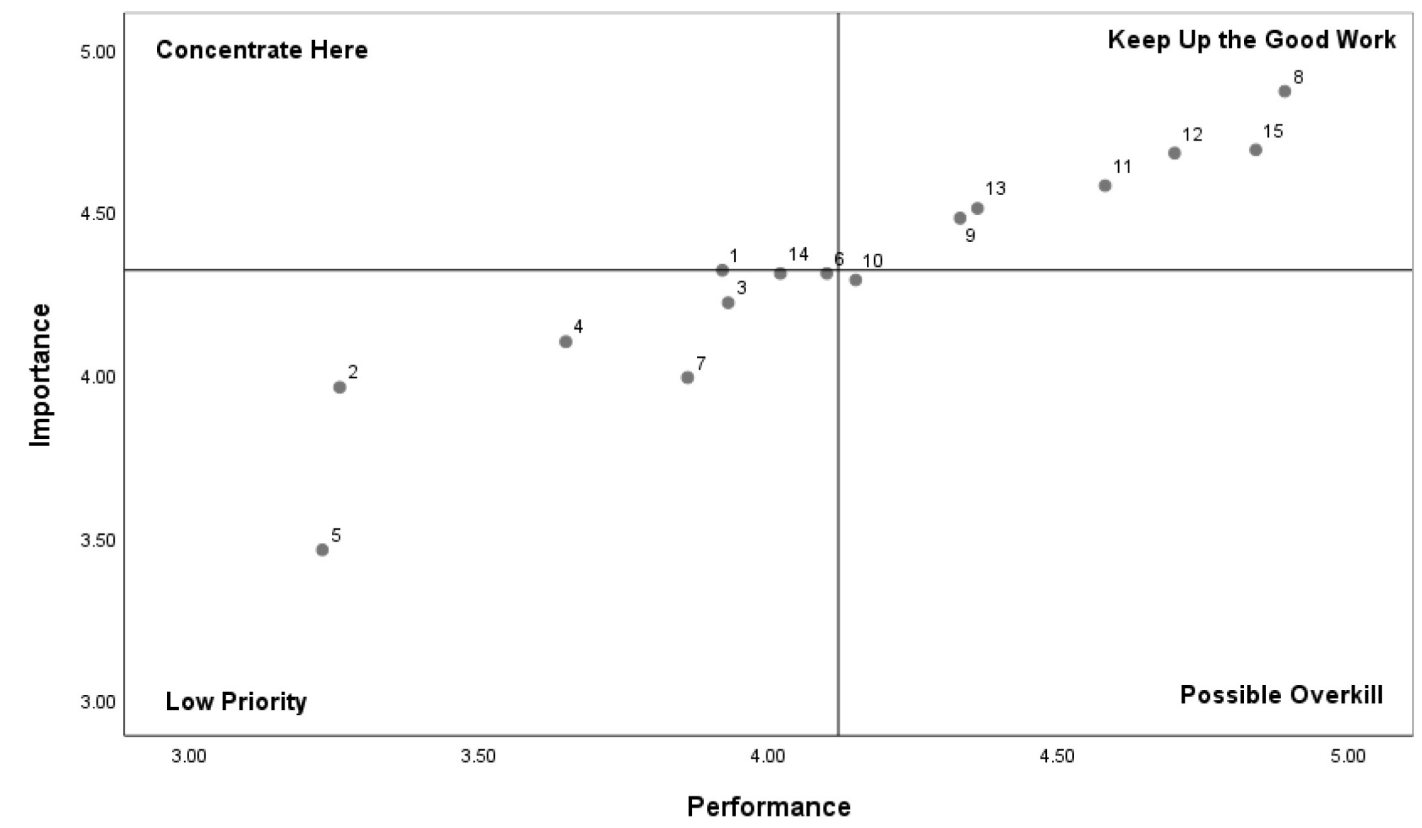

\begin{tabular}{|cclll|}
\hline $\begin{array}{c}\text { Keep UP } \\
\text { the }\end{array}$ & 8 & Using natural seasonings & 12 Blanching processed meat \\
$\begin{array}{c}\text { Good } \\
\text { Work }\end{array}$ & 9 & Lowering salinity of seasonings & 13 & Serving seasonings separately \\
\hline & 11 & Adding seasoning just before serving soup & 15 & Posting soup salinity \\
\hline $\begin{array}{c}\text { Low } \\
\text { Priority }\end{array}$ & 2 & Choosing low-sodium seasonings & 5 & $\begin{array}{l}\text { Planning a menu with only one or two salty } \\
\text { dishes }\end{array}$ \\
& 4 & Planning a low-sodium menu & 6 & Decreasing the use of processed foods \\
\hline $\begin{array}{l}\text { Possible } \\
\text { Overkill }\end{array}$ & 10 & Using more spice, herb or perilla powders & 7 & Soaking cabbage in brine instead of salting \\
\hline
\end{tabular}

Fig. 1. Importance-Performance Analysis of sodium reduction methods in school foodservice. 
중요도 인식과 수행도가 낮아 향후 개선이 필요한 부문인 3 사분면 (Low priority)에는 1 (영양표시의 나트륨함량 확 인하기), 2 (저염 양념류 구매하기), 3 (나트륨함량 고려하여 식단 작성하기 $), 4$ (칼륨이 풍부한 식단 작성하기 $), 5$ (한 . 두 음식에만 집중적으로 간하도록 식단을 조정하기), 6 (가 공완제품 사용하는 대신 직접 조리하도록 식단 작성하기), 7 (채소 절일 때 소금 대신 소금물을 사용하기), 14 (용량 작 은 국그릇 사용하거나 양을 적게 배식하기)로 나타났다.

중요도가 낮지만, 수행도가 높아 중요도에 비하여 많은 노 력이 투입되었다고 평가된 4사분면 (Possible overkill)에 해당된 항목은 10 (소금과 장류 사용량을 줄이고 향신료, 허 브, 들깨가루 등을 사용하기)이었다. 하지만 중요도 (4.29) 와 수행도 (4.15)가 평균값에 근접한 값이었다.

\section{3. 나트륨 저감화 교육 실시 여부 및 방법}

학교에서 급식종사자 (조리사, 조리종사원)를 대상으로 한 나트륨 저감화 교육 실시 여부 및 방법에 대한 분석 결과는 Table 5와 같다. 급식종사자를 대상으로 나트륨 저감화에 대한 교육을 실시하고 있는 비율이 초등학교는 $89.9 \%$, 중학 교는 $93.5 \%$, 고등학교는 $95.8 \%$ 로 고등학교에서 초등학교 에 비하여 실시율이 유의하게 높았다 $(P<0.05)$. 교육 빈도 는 전체적으로 '1 2회/월' 실시하는 경우가 전체 $37.9 \%$ 로 가장 높게 나타났고, '1 2회/년'는 30.2\%, '1 2회/주'는 $15.4 \%$ 였으며, 월 1 2회 이상 실시하는 비율이 초등학교는 $68 \%$, 중학교는 $63 \%$, 고등학교는 $87 \%$ 로 초등학교와 중학 교에 비하여 고등학교에서 교육빈도가 유의하게 높았다 $(P$ $<0.05)$. 교육 방법은 다중응답으로 조사한 결과, 집합교육 이 $52.9 \%$ 로 가장 높았으며, 인쇄매체를 활용한 교육이 전체

Table 5. Sodium reduction education practice for school foodservice workers and education methods

\begin{tabular}{|c|c|c|c|c|c|}
\hline Item & $\begin{array}{c}\text { Elementary } \\
\text { school }\end{array}$ & Middle school & High school & Total & $\chi^{2}$ \\
\hline \multicolumn{6}{|l|}{ How often sodium reduction education is provided } \\
\hline Every day & $11(8.5)$ & $4(8.7)$ & $3(12.5)$ & $18(9.0)$ & 18.726* \\
\hline Often & $42(32.6)$ & $5(10.9)$ & $8(33.3)$ & $55(27.7)$ & \\
\hline Sometimes & $63(48.8)$ & $34(73.9)$ & $12(50.0)$ & $109(54.8)$ & \\
\hline Hardly & $11(8.5)$ & $0(0.0)$ & $1(4.2)$ & $12(\quad 6.0)$ & \\
\hline Never & $2(1.6)$ & $3(6.5)$ & $0(0.0)$ & $5(2.5)$ & \\
\hline Total & $129(100.0)$ & $46(100.0)$ & $24(100.0)$ & $199(100.0)$ & \\
\hline \multicolumn{6}{|l|}{ Frequency of sodium reduction education } \\
\hline Every day & $15(12.9)$ & $3(7.0)$ & $4(17.4)$ & $22(12.2)$ & $19.371 *$ \\
\hline $3 \sim 4$ times/week & $4(3.4)$ & $3(7.0)$ & $0(0.0)$ & $7(3.8)$ & \\
\hline $1 \sim 2$ times/week & $21(18.2)$ & $3(7.0)$ & $4(17.4)$ & $28(15.4)$ & \\
\hline $1 \sim 2$ times/month & $39(33.6)$ & $18(41.9)$ & $12(52.2)$ & $69(37.9)$ & \\
\hline 1 2 times/year & $37(31.9)$ & $16(37.1)$ & $2(8.7)$ & $55(30.2)$ & \\
\hline Others & $0(\quad 0.0)$ & $0(0.0)$ & $1(4.3)$ & $1(\quad 0.5)$ & \\
\hline Total & $116(100.0)$ & $43(100.0)$ & $23(0.0)$ & $182(100.0)$ & \\
\hline \multicolumn{6}{|l|}{ Methods of sodium reduction education'l) } \\
\hline Use of bulletin boards & $10(7.5)$ & $4(8.5)$ & $3(10.3)$ & $17(8.1)$ & 0.586 \\
\hline Collective education & $73(54.4)$ & $23(48.9)$ & $15(51.7)$ & $111(52.9)$ & 1.097 \\
\hline Use of printed media & $39(29.1)$ & $15(31.9)$ & $7(24.2)$ & $61(29.0)$ & 0.118 \\
\hline Others & $12(9.0)$ & $5(10.7)$ & $4(13.8)$ & $21(10.0)$ & 1.169 \\
\hline Total & $134(100.0)$ & $47(100.0)$ & $29(100.0)$ & $210(100.0)$ & \\
\hline \multicolumn{6}{|c|}{ Reasons for not running a sodium reduction education program } \\
\hline Lack of education materials & $3(23.1)$ & $3(100.0)$ & $1(100.0)$ & $7(41.2)$ & 7.473 \\
\hline Lack of time for the education & $8(61.5)$ & $0(0.0)$ & $0(0.0)$ & $8(47.0)$ & \\
\hline Lack of educatees' will to change their awareness & $0(0.0)$ & $0(0.0)$ & $0(0.0)$ & $0(0.0)$ & \\
\hline Not feeling the need for the education & $2(15.4)$ & $0(0.0)$ & $0(0.0)$ & $2(11.8)$ & \\
\hline Others & $0(0.0)$ & $0(0.0)$ & $0(0.0)$ & $0(0.0)$ & \\
\hline Total & 13 (100.0) & $3(100.0)$ & 1 (100.0) & 17 (100.0) & \\
\hline
\end{tabular}

$\mathrm{n}(\%), * P<0.05$

1) Duplicate answers 
Table 6. Needs for policy support to activate sodium reduction practice

\begin{tabular}{|c|c|c|c|c|c|}
\hline Item & $\begin{array}{l}\text { Elementary school } \\
\qquad(\mathrm{n}=129)\end{array}$ & $\begin{array}{l}\text { Middle school } \\
\quad(n=46)\end{array}$ & $\begin{array}{l}\text { High school } \\
(\mathrm{n}=24)\end{array}$ & $\begin{array}{c}\text { Total } \\
(n=199)\end{array}$ & F-value \\
\hline $\begin{array}{l}\text { Development of low-sodium cooking methods for } \\
\text { school meal providers }\end{array}$ & $4.50 \pm 0.65$ & $4.35 \pm 0.71$ & $4.38 \pm 0.92$ & $4.45 \pm 0.70$ & 1.006 \\
\hline $\begin{array}{l}\text { Development of low-sodium traditional Korean } \\
\text { sauce }\end{array}$ & $4.43 \pm 0.71$ & $4.24 \pm 0.67$ & $4.13 \pm 1.03$ & $4.35 \pm 0.75$ & 2.428 \\
\hline Setting standards of salt and sodium levels & $4.02 \pm 1.01$ & $4.09 \pm 0.86$ & $4.00 \pm 0.93$ & $4.04 \pm 0.97$ & 0.091 \\
\hline Development of low-sodium foods for school meals & $4.48 \pm 0.67$ & $4.33 \pm 0.63$ & $4.54 \pm 0.59$ & $4.45 \pm 0.66$ & 1.195 \\
\hline $\begin{array}{l}\text { Mandatory presentation of the salt levels of each } \\
\text { menu }\end{array}$ & $3.50 \pm 1.12$ & $3.72 \pm 1.00$ & $3.67 \pm 1.13$ & $3.57 \pm 1.09$ & 0.745 \\
\hline $\begin{array}{l}\text { Activating sodium reduction education for school } \\
\text { meal workers }\end{array}$ & $4.29 \pm 0.72$ & $4.43 \pm 0.65$ & $4.25 \pm 0.68$ & $4.32 \pm 0.70$ & 0.880 \\
\hline $\begin{array}{l}\text { Activating sodium reduction education for students } \\
\text { and parents }\end{array}$ & $4.48 \pm 0.65$ & $4.39 \pm 0.71$ & $4.21 \pm 0.78$ & $4.43 \pm 0.68$ & 1.696 \\
\hline $\begin{array}{l}\text { Promoting sodium reduction education in school } \\
\text { administrator (principal, vice principal) training } \\
\text { sessions }\end{array}$ & $4.38 \pm 0.72$ & $4.37 \pm 0.77$ & $4.21 \pm 0.83$ & $4.36 \pm 0.74$ & 0.544 \\
\hline Dissemination of low-sodium menus & $4.37 \pm 0.72$ & $4.37 \pm 0.74$ & $4.29 \pm 1.00$ & $4.36 \pm 0.76$ & 0.116 \\
\hline $\begin{array}{l}\text { Realignment of the NEIS program (for an accurate } \\
\text { calculation of sodium content and convenient } \\
\text { use) }\end{array}$ & $4.22 \pm 0.92$ & $4.41 \pm 0.86$ & $4.17 \pm 1.01$ & $4.26 \pm 0.92$ & 0.907 \\
\hline
\end{tabular}

Mean \pm S.D.

$29.0 \%$ 로 조사되었다. 나트륨 저감화 교육을 실시하지 않는 다고 응답한 학교 중 실시하지 못하는 이유로 ‘교육할 시간 부족’이 전체 $47.0 \%$ 로 가장 높았다.

\section{4. 나트륨 저감화 활성화를 위한 정책적 지원의 필요성}

나트륨 저감화 사업의 활성화를 위한 정책 지원의 필요성 에 대한 분석 결과는 Table 6 과 같다. '급식소 기준 저염 조 리법 개발'과 ‘단체급식용 나트륨 저감화 식품개발'이 각각 전체 4.45점, 4.45점으로 필요성이 가장 높았고, ‘학생과 학 부모 대상으로 한 나트륨 관련 교육의 활성화'가 4.43점, “나 이스 (NEIS) 프로그램의 정비 (나트륨함량 계산의 정확성과 사용의 편리성 ' 4.26 점으로 필요성이 높게 나타났다. 학교 급간 유의한 차이는 없었다.

\section{고 찰}

대구지역 2018년 학교급식 나트륨 저감화 실태를 조사한 결과, 전체 학교의 $100 \%$ 가 염도를 측정하고 있으며, 매일 측정하는 비율이 $98.5 \%$ 로 매우 높은 것으로 조사되었다. 이 는 2012년 경기지역 [3] 62.7\%, 2013년 전국 [9] 52.1\%, 2014년 서울지역 [5] 70.8\%, 2015년 울산지역 [7] 97.3\% 보다 높았으며, 해가 거듭됨에 따라 전국적으로 학교급식에 서 염도를 매일 측정하는 비율이 점차 높아지고 있다. 염도 측정담당자는 조리사인 경우가 $59.3 \%$ 로 가장 높았지만 제
주지역 [8]의 조리사가 측정하는 비율이 $83.1 \%$ 인 것에 비 하면 낮은 수치였다. 저나트륨 식단을 제공하는 경우는 $77.4 \%$ 로 서울지역 [5] 57.5\%보다 높은 것으로 나타났다. 가공식 품 사용빈도는 주 1 2회 제공하는 경우가 $49.7 \%$ 로 가장 높 았고, 월 1 2회가 $43.3 \%$, 주 3 4회가 $6.5 \%$ 였는데, 이는 경기지역 [4]의 가공식품 사용빈도인 주 1 회 미만 $50.5 \%$ 와 유사한 결과였다.

학교별 국류의 평균 염도는 초등학교가 $0.50 \%$ 이고, 중학 교는 $0.52 \%$, 고등학교는 $0.54 \%$ 로 교육부 권장 염도인 초 등학교와 중학교 $0.6 \%$ 이하, 고등학교 $0.7 \%$ 이하를 준수하 는 것으로 나타났다. 경기지역 [3] 학교급식의 경우 0.7 $0.8 \%$ 인 경우가 $49.0 \%$ 로 약간 높은 편이었는데 이는 본 연 구보다 6년 전의 결과라서 다소 높았을 것으로 사료된다. 비 슷한 시기의 대구지역 [10] 어린이집 급식의 국물류 염도인 해물국류가 $0.45 \%$, 된장국류가 $0.44 \%$, 맑은국류와 들깨국 류 $0.42 \%$ 보다는 높았다. 찌개류의 평균 염도는 초등학교가 $0.58 \%$ 로 가장 낮았고, 고등학교가 $0.66 \%$ 로 가장 높았는데 이는 2013년 경기지역 [11]의 어린이집과 유치원 급식 찌 개류 평균 염도 $0.95 \%$ 보다는 오히려 낮았다. 또한 찌개류의 염도 $(0.60 \%)$ 가 국류의 염도 $(0.51 \%)$ 보다 유의하게 높았 는데 이는 전국 가정식, 급식, 외식 음식의 염도를 분석한 연 구 [12]에서 가정식과 외식의 경우 된장찌개가 각각 $1.12 \%$, $1.17 \%$ 로 다른 국물류에 비하여 유의하게 높았으나 단체급 식의 경우 국 - 찌개 - 탕류 염도 간 유의한 차이가 없었던 것 
과 비교하면 상이한 결과였다. 고나트륨 한식 대표 음식의 염 도 저감화 기준치 개발 연구 [13]에서 염도 저감화 기준치를 맑은국 (콩나물국, 미역국) $0.5 \%$, 맑은 탕류 (복어탕, 동태 탕) $0.6 \%$, 토장국류 (시금치된장국, 아욱된장국 등) · 일반 탕류 (육개장 등) 및 찌개류 (순두부찌개 등) $0.7 \%$, 토장찌 개 (된장찌개) $0.8 \%$ 순으로 제시한 바 있다. 이 기준치와 비 교하더라도 대구지역 학교급식의 국 및 찌개류의 염도는 적 절한 것으로 보여진다.

저나트름 식단 제공 시 가장 어려운 점으로 ‘급식 만족도 가 낮아질 것에 대한 염려', ‘학생, 교직원 등 피급식자 인식 과 실천의식 부족’이라고 답한 비율이 높게 나타났다. 이는 서울지역 [7] 영양(교)사를 대상으로 한 조사 결과인 '피급 식자의 맛에 대한 인식을 변화시키기가 어렵다' $40.8 \%$, '맛 이 없다는 불평이 많다' $40.0 \%$ 와 유사하였다.

나트륨 저감화 방법에 대한 중요도와 수행도 분석 결과 조 리단계에서 ‘천연조미료 사용하기', ‘쌈장, 된장은 두부나 양 파 등을 갈아 염도를 낮추기', ‘국 - 찌개는 끓인 후 마지막에 간하기', ‘어육가공품은 데친 후 조리하기'와 배식단계에서 ‘양념장은 별도로 배식하기', ‘국 · 탕 - 찌개류의 염도 게시 하기, 항목은 중요하게 인식하는 만큼 충분히 수행되고 있으 며, 지속적으로 유지관리가 필요한 항목 (Keep up the good work)이었다. 이 중 ‘천연조미료 사용하기'를 가장 중요하 게 인식하였고, 수행도도 가장 높았다. 그다음은 ‘국 · 탕 . 찌개류의 염도 게시하기'였으며, 유일하게 중요도보다 수행 도가 더 높은 항목이었다. 실제로 본 연구에서 대구지역 학 교급식소의 $98.5 \%$ 가 매일 염도를 측정한다고 답하여 그 수 행도가 매우 높음을 알 수 있다.

중요도 인식과 수행도가 낮은 3사분면 (Low priority)에 해당하는 항목이면서 중요도에 비해 수행도가 유의하게 낮 은 항목으로는 구매단계의 ‘저염 양념류 구매하기', ‘영양표 시의 나트륨 함량 확인하기', 식단작성 단계의 '나트륨함량 고려하여 식단 작성하기', '칼륨이 풍부한 식단 작성하기', '한 · 두 음식에만 집중적으로 간하도록 식단을 조정하기', '가공완제품 사용하는 대신 직접 조리하도록 식단 작성하기' 였다. 이들 항목은 향후 효과적으로 나트륨 저감화를 활성화 하기 위해서 개선이 필요한 항목으로 볼 수 있으며, 울산지 역 [7] 학교급식 결과도 본 연구 결과와 유사하였다. 수행도 가 중요도보다 가장 낮았던 항목은 '저염 양념류 구매하기' 였는데, 이는 부산지역 [6] 중학교 영양(교)사 대상 조사 결 과에서도 ‘저염 제품 (소금, 간장, 고추장, 된장)을 사용한다 ,의 실천도 점수가 2.97점으로 가장 낮았다는 결과와 유사 하였다. 또한 경기지역에서는 전체 초 - 중 - 고등학교의 $90.5 \%$ 가 저염 제품을 사용하지 않았는데, 그 이유가 정보
부족 $(48.4 \%)$ 과 비싼 가격 (27.2\%) 때문으로 보고된 바 있 다 [4]. 그러나 최근 국내 장류의 나트륨함량을 낮추자 판매 량은 급증했다는 보도 [15]가 있다. 즉 A식품업체는 일반 간 장 대비 염도를 $28 \%$ 낮추고, 감칠맛의 원천인 ‘글루타민'이 풍부한 국내산 다시마를 유산균 발효시켜 풍미를 한층 높인 결과, 매출이 지난해 동기 대비 $16.2 \%$ 증가했다고 한다.

조리사와 조리종사원을 대상으로 나트륨 저감화에 대한 교육을 실시하고 있는 비율은 '매일 한다', ‘자주 한다'와 '가 끔 한다’로 응답한 경우가 전체 $91.5 \%$ 로 초등학교는 $89.9 \%$, 중학교는 $93.5 \%$, 고등학교는 $95.8 \%$ 로 유의한 차이가 있 었다.

나트륨 저감화 활성화를 위해 ‘저염 조리법 개발', '나트륨 저감화 식품개발’과 ‘학생과 학부모 대상 나트륨 저감화 관 련 교육 활성화에 대한 정책적 지원'이 필요한 것으로 나타 났다. Lee [14]의 연구에서는 나이스 프로그램의 가공식품 의 나트륨 성분을 파악한 결과 조사 건수 467 건 중 184 건 의 식품류의 나트륨함량 표기가 0으로 되어있어 $39.4 \%$ 의 데이터에 나트륨 측정이 정확하지 않은 것을 지적하였다. 학 교급식에서 나트륨 저감화를 활성화시키기 위해서는 나이스 프로그램의 영양소별 데이터 수정과 지속적인 모니터링이 필 요하다. 또한 고나트륨 한식 대표 음식의 염도 저감화 기준 치 연구 [13]에서 제시한 바와 같이 학교급식에서도 음식군 별 염도 저감화 기준치 설정을 위한 연구가 필요할 것으로 사 료된다.

\section{요약 및 결론}

본 연구는 대구지역에 근무하는 초 · 중 · 고등학교 전체 영양(교)사를 대상으로 학교급식의 나트륨 저감화 실태 관 련 설문조사를 2018년 2 4월에 걸쳐 실시하였으며, 응답 자 199명 (회수율 44.2\%)에 대한 설문 분석 결과는 다음과 같다.

학교급식의 국과 찌개류의 염도를 매일 측정하는 비율은 $98.5 \%$ 로 높았고, 염도 측정담당자는 초등학교 (68.2\%)와 중학교 $(52.2 \%)$ 에서는 ‘조리사'가 주로 담당했고, 고등학교 (70.8\%)에서는 ‘영양 (교)사’가 대부분 담당하고 있었다. 전 체적으로 학교급식 찌개류의 염도 $(0.60 \%)$ 가 국류의 염도 $(0.51 \%)$ 보다 유의하게 높았다 $(P<0.001)$. 국류의 평균염 도는 고등학교 $(0.54 \%)$ 가 초등학교 $(0.50 \%)$ 에 비해 유의 하게 높았으며 $(P<0.05)$, 찌개류의 평균 염도는 고등학교 $(0.66 \%)$ 에서 중학교 $(0.62 \%)$ 와 초등학교 $(0.58 \%)$ 보다 유 의하게 높았다 $(P<0.001)$. 저나트륨 식단을 제공하는 빈 도는 초등학교에서는 '매일' 제공이 가장 높았고, 중학교와 
고등학교는 월 1 2회 제공 빈도가 가장 높았다 $(P<0.05)$. 저나트륨 식단 제공 시 가장 어려운 점은 '급식 만족도가 낮 아질 것에 대한 염려'가 전체 $27.3 \%$ 로 가장 높게 나타났다.

나트륨 저감화 방법에 대한 중요도와 수행도 분석 결과 중 요도와 수행도가 모두 높은 항목 (Keep up the good work)은 ‘천연조미료 사용하기’, ‘쌈장, 된장은 두부나 양파 등을 갈아 염도 낮추기', ‘국 - 찌개는 끓인 후 마지막에 간하 기', ‘어육가공품 데친 후 조리하기', ‘양념장은 별도 배식하 기', ‘국 - 탕 - 찌개류의 염도 게시하기'의 조리단계 4항목과 배식단계 2항목의 총 6항목이었다. 3 사분면 (Low priority) 에 속하면서 중요도보다 수행도가 유의하게 낮은 항목은 양 념류 구매 시 저염 제품 선택하기' $(P<0.001)$, '영양표시 의 나트륨함량 확인하기 $(P<0.001)$ ', '칼륨이 풍부한 식단 작성하기' $(P<0.001)$, '나트륨함량 고려하여 식단 작성하 기' $(P<0.001)$, '한두 가지 음식에 집중적으로 간하도록 식 단 조정하기' $(P<0.05)$, '가공완제품 사용하는 대신 직접 조리하도록 식단 작성하기' $(P<0.05)$ 로 구매단계 2 항목과 식단작성단계 4 항목의 총 6 항목이었다.

나트륨 저감화 사업을 활성화하기 위한 정책적 지원의 필 요성 조사 결과 ‘급식소 기준 저염 조리법 개발', '단체급식 용 나트륨 저감화 식품개발’에 대한 필요성이 가장 높았고, ‘학생과 학부모 대상으로 한 나트륨 관련 교육의 활성화', '저 염식 메뉴 책자 보급’, ‘학교관리자 (교장, 교감) 연수 시 나 트륨 저감화 교육 홍보' 순으로 필요성이 인식되고 있었다.

본 연구결과, 학교급식 나트륨 저감화를 효과적으로 활성 화하기 위해서는 학교급식 저나트륨 식단 및 조리법 개발이 우선하여 이루어져야 하겠다. 또한 구매 및 식단작성 시 나 이스 프로그램에서 식품 및 가공식품의 정확한 나트륨 함량 이 확인될 수 있어야 하며, 음식군별 나트륨 제공량에 대한 구체적인 학교급식 기준 마련 등의 정책적 지원이 필요할 것 으로 사료된다.

\section{ORCID}

Su-Hyeon Kim: https://orcid.org/0000-0001-5990-9436

Eun-Kyung Shin: https://orcid.org/0000-0003-3269-5276

Yeon-Kyung Lee: https://orcid.org/0000-0002-5975-3969

\section{References}

1. Ministry of Education Student Health Information Center. School foodservice execution status [internet]. 2019 [updated 2019 May
31; cited 2019 Aug 5]. Available from: http://www.schoolhealth. $\mathrm{kr} / \mathrm{web} / \mathrm{bbs} / \mathrm{selectBBSList.do}$ ?bbsTyCode $=$ BBST01\&bbsId $=0201$ \&lstnum $1=2856 \&$ pageIndex $=1 \&$ pageUnit $=10 \&$ dataType $=\&$ search $\mathrm{Cnd}=\&$ searchWrd $=$.

2. Ministry of Education. Sodium reduction of school foodservice guide book [internet]. 2014 [updated 2014 Feb 27; cited 2018 Mar 13]. Available from: https://www.moe.go.kr/boardCnts/view. do?boardID $=316 \&$ boardSeq $=52712 \& l e v=0 \& m=0302$.

3. Lee KS. Use of salimeters and sodium reduction education in school foodservice in the Gyeonggi area. J Korean Diet Assoc 2013; 19(2): 173-181.

4. Lee JH. Awareness and practice of sodium reduction by elementary, middle and high school dietitians in Gyeonggi area. JEast Asian Soc Dietary Life 2012; 22(6): 734-743.

5. Yu KH. The investigation of actual condition about sodium reduction practice for school food service by nutritionist's sodium related eating habits in Seoul area [master's thesis]. Sookmyung Women's University; 2014.

6. Ha IH, Lyu ES. Awareness, practice, and obstruction of sodium reduction by middle school dietitians in Busan area. Korean J Food Cook Sci 2015; 31(2): 225-232.

7. Lee MJ. Survey on the current state of sodium reduction according to dietary behavior and nutrition knowledge of school dietitian [master's thesis]. Kyungnam University; 2015.

8. Jung MJ. A study on the dietary behaviors related to the sodium intake and the sodium reduction enforcement status in school meals by the school nutrition teachers and dietitians in Jeju [master's thesis]. Jeju National University; 2015.

9. Kim EK, Kim HY. School dietitian awareness, practice, and sodium reduction plan in school meal service. Korean J Food Cook Sci 2016; 32(2): 222-232.

10. Lee NY, Lee YK. Comparison of salinity and sodium content by the salinity measurement frequency of soups of child-care centers enrolled in the Center for Children's Food Service Management in Daegu. Korean J Community Nutr 2020; 25(1): 13-20.

11. Kim JN, Park SY, Ahn SH, Kim HK. A survey on the salt content of kindergarten lunch meals and meal providers' dietary attitude to sodium intake in Gyeonggi-do area. Korean J Community Nutr 2013; 18(5): 478-490.

12. Jiang L, Shin D, Lee YK. Salinity of representative Korean foods high in sodium from home meals, foodservice, and restaurants. Korean J Community Nutr 2018; 23(4): 333-340.

13. Jiang L, Shin EK, Seo JS, Lee YK. Development of standards for reducing the sodium content and salinity of Korean fermented soybean sauce and representative Korean foods high in sodium. J Nutr Health 2019; 52(2): 185-193.

14. Lee KS. Study on the perception of school dietitians about sodium and the analysis on sodium reduction using NEIS [master's thesis]. Kyonggi University; 2013.

15. Kim BR. "I hate sodium"... Winged low-sodium product. The Seoul Economic Daily; 2020 [cited 2020 Sep 5]. Available from: https://www.sedaily.com/NewsVIew/1Z5D55JS5F. 